\title{
THE EFFECT OF SODIUM SELENITE TREATMENT IN AN EXPERIMENTAL MODEL OF ACUTE GLYPHOSPHATE POISONING
}

\section{WPLYW ZASTOSOWANIA SELENINU SODU W EKSPERYMENTALNYM MODELU ZATRUCIA GLIFOSATEM}

\author{
Oleksandr Oliynyk ${ }^{1(\mathrm{~A}, \mathrm{~B}, \mathrm{C}, \mathrm{D}, \mathrm{E}, \mathrm{F})}$
}

${ }^{1}$ Pope John Paul II State School of Higher Education in Biała Podlaska, Poland

Authors' contribution Wkład autorów:

A. Study design/planning zaplanowanie badań

B. Data collection/entry zebranie danych

C. Data analysis/statistics dane - analiza i statystyki D. Data interpretation interpretacja danych E. Preparation of manuscript przygotowanie artykułu F. Literature analysis/search wyszukiwanie $i$ analiza literatury G. Funds collection zebranie funduszy
Tables: 1

Figures: 0

References: 16

Submitted: 2020 March 27

Accepted: 2020 May 5

\section{Summary}

Background. The aim of this study was to investigate the possibility of using sodium selenite as a treatment for acute glyphosate poisoning using the activity of the lipid peroxidation and antioxidant defence systems as a readout for efficacy.

Material and methods. Experimental glyphosate poisoning and subsequent treatment using sodium selenite was performed in albino rats (105). Glyphosate was given in doses of 50, 100 and $130 \mathrm{mg} / \mathrm{kg}$, and sodium selenite was administered at a dose of $2 \mu \mathrm{g} / \mathrm{kg}$. The blood concentrations of lipid peroxidation markers including conjugates of diene andtrienoic and malondialdehyde were determined. The endogenous glutathione (reduced form) level and activities of catalase, superoxide dismutase and glutathione peroxidase in the serum were measured.

Results. Glyphosate poisoning has been found to result in a significant increase in lipid peroxidation activity. For example, malonic dialdehyde demonstrates a 2.35 times increase at a glyphosate dose of $130 \mathrm{mg} / \mathrm{kg}$. At the experimental glyphosate poisoning dose of $100 \mathrm{mg} /$ $\mathrm{kg}$ the measurements of superoxide dismutase and glutathione peroxidase have been found to decrease 1.58 and 2.21 times, respectively. At a dose of $130 \mathrm{mg} / \mathrm{kg}$, those values decreased 2.51 and 4.76 times, respectively, compared to untreated controls.

Conclusions. The use of sodium selenite at a dose of $2 \mu \mathrm{g} / \mathrm{kg}$ after poisoning of white rats with glyphosate (at doses of 50,100 and $130 \mathrm{mg} / \mathrm{kg}$ ) normalizes the lipid peroxidation and antioxidant defence activities of the body.

Keywords: lipid peroxidation, antioxidants, glyphosate poisoning

\section{Streszczenie}

Wprowadzenie. Celem niniejszej pracy było zbadanie możliwości zastosowania seleninu sodu w leczeniu ostrego zatrucia glifosatem wykorzystując aktywność peroksydacji lipidów oraz antyoksydacyjnych układów ochronnych jako wskaźnik skuteczności.

Materiał i metody. 105 szczurów albinosów poddano eksperymentalnemu zatruciu glifosatem i leczeniu seleninem sodu. Glifosat został zastosowany w dawkach 50, $100 \mathrm{i} 130 \mathrm{mg} / \mathrm{kg}$. Selenin sodu podawano $\mathrm{w}$ dawce $2 \mu \mathrm{g} / \mathrm{kg}$. Oznaczono stężenie markerów peroksydacji lipidów we krwi: koniugatów dien i trienoicznych oraz dwualdehydu maleinowego. Zbadano poziom endogennego glutationu (w zredukowanej formie) oraz aktywność katalazy, dysmutazy ponadtlenkowej i peroksydazy glutationowej w surowicy krwi.

Wyniki. Stwierdzono, że zatrucie glifosatem powoduje znaczny wzrost aktywności peroksydacji lipidów. Przykładowo, poziom dwualdehydu maleinowego wzrósł 2,35 razy w przypadku dawki glifosatu wynoszącej $130 \mathrm{mg} / \mathrm{kg}$. Stwierdzono również, że wskaźniki dysmutazy ponadtlenkowej i peroksydazy glutationowej zmniejszają się odpowiednio 1,58 i 2,21 w eksperymentalnym zatruciu glifosatem w dawce $100 \mathrm{mg} / \mathrm{kg}$. Zaobserwowane wartości zmniejszyły się 2,51 i 4,76 razy podczas zastosowania dawki $130 \mathrm{mg} / \mathrm{kg}$ w porównaniu z grupą kontrolną zdrowych zwierząt.

Wnioski. Zastosowanie seleninu sodu w dawce $2 \mu \mathrm{g} / \mathrm{kg}$, aby przeciwdziałać zatruciu glifosatem w dawkach 50, 100 i $130 \mathrm{mg} / \mathrm{kg}$ u szczurów albinosów, normalizuje peroksydację lipidów i czynności obrony antyoksydacyjnej organizmu.

Słowa kluczowe: peroksydacja lipidów, antyoksydanty, zatrucie glifosatem 


\section{Introduction}

Increasing lipid peroxidation is a common mechanism in a number of pathologies. Glyphosate (Gl), an agent used for fighting weeds, is the most popular herbicide worldwide. About 800,000 tons are produced and embedded into the soil annually [1]. Gl has an affinity for most organs of the human body, especially the liver, kidneys and brain. Gl increases the risk of tumors, infertility and embryonic disorders in humans and animals [2]. Symptoms of acute Gl poisoning include gastroenteritis, respiratory failure, impaired consciousness, decreased blood pressure, renal failure, and shock when the daily dose is higher than $125 \mathrm{mg} / \mathrm{kg}$ [3]. Therefore, the study of drugs that could be used in the treatment of Gl poisoning is important.

One of the natural antioxidants that enters the human body through food is sodium selenite (S) [4]. Given that $\mathrm{Gl}$ is a strong prooxidant, a substance with antioxidant activity, such as S, should theoretically have a therapeutic effect against Gl poisoning. Many toxic substances have dose-dependent effects. It is not known to what extent the toxic properties of Gl depend on its dose and whether S would be effective as a treatment in acute Gl poisoning. In this study, various doses of Gl were given and the activity of the lipid peroxidation and enzymes of the antioxidant defense system were studied.

\section{Material and methods}

Albino male rats (105) with the body weight 180-220 g were used for this study. The rats were kept in Fengshi plastic cages, 5 per cage, with wooden chips. The light conditions were 12 hours of light and 12 hours of dark. The temperature was maintained at $19-25^{\circ} \mathrm{C}$. The relative humidity was $50-70 \%$. Temperature and humidity measurements were taken daily. Ventilation was controlled with an anemometer and by measuring carbon dioxide and ammonia air content. The ventilation protocol was set to provide 15 room volumes per hour with a carbon dioxide concentration up to $0.15 \%$ volume and ammonia concentration of up to $0.001 \mathrm{mg} / \mathrm{l}$. The rats were fed twice a day and water was available ad libitum. The regulations of the European Convention for the Protection of Vertebrate Animals used for Experimental and Other Scientific Purposes (Strasbourg, 1986) were strictly followed [5]. The animals were randomized into 7 groups $(n=15): 1$, healthy animals that received $1 \mathrm{ml}$ of $0.9 \%$ saline solution intraperitoneally for two days and $1 \mathrm{ml}$ of $0.9 \%$ saline solution for two days enterally; 2 , animals that received $\mathrm{Gl}$ at a dose of $50 \mathrm{mg} / \mathrm{kg}$ intraperitoneally for two days; 3, animals that received Gl at a dose of $100 \mathrm{mg} / \mathrm{kg}$ intraperitoneally for two days; 4, animals that received Gl at a dose of $130 \mathrm{mg} / \mathrm{kg}$ intraperitoneally for two days; 5, animals that received Gl at a dose of $50 \mathrm{mg} / \mathrm{kg}$ intraperitoneally for two days and $\mathrm{S}$ at a dose of $2 \mu \mathrm{g} / \mathrm{kg}$ [4] for two days enterally; 6, animals that received Gl at a dose of $100 \mathrm{mg} / \mathrm{kg}$ intraperitoneally for two days and $\mathrm{S}$ at a dose of $2 \mu \mathrm{g} / \mathrm{kg}$ for two days enterally; 7, animals that received Gl at a dose of $130 \mathrm{mg} / \mathrm{kg}$ and $\mathrm{S}$ at a dose of $2 \mu \mathrm{g} / \mathrm{kg}$, given on the same schedule as in the group 6 . The animals were euthanized by intraperitoneal propofol injection $(10 \mathrm{mg} / \mathrm{kg})$, after which the blood was collected from the jugular vessels following decapitation. The concentration of the lipid peroxidation markers diene and trienoic conjugates (DC and TC) and malondialdehyde (MDA) in the blood was determined. Endogenous glutathione level (reduced form) was measured spectrophotometrically (Shimazu UV-VIS, Japan) according to the method of Gronwald et al. Catalase (C), superoxide dismutase (SOD) and glutathione peroxidase (GTPR) activity in the blood serum was determined [6].

The experiments were conducted in the central research laboratory of I. Horbachevsky Ternopil National Medical University, Ukraine, according to the agreement of scientific cooperation between I. Horbachevsky Ternopil National Medical University and Pope John Paul II State School of Higher Education in Biała Podlaska, Poland. Permission to conduct the experiments was issued by the bioethics commission of I. Horbachevsky Ternopil National Medical University.

The data were analyzed using the variation statistical method, the Mann-Whitney test. Mean arithmetic value (M), mean arithmetic errors (m), variation coefficients and mean quadratic deviations were calculated. Differences were regarded as reliable at $p \leq 0.001$. The significance level in the tables was specified for reliable results only. Microsoft Excel XP (USA) and Statsoft STATISTICA programs were used for calculations.

\section{Results}

Gl poisoning in different doses was found to reproducibly increase the blood serum levels of intermediary lipid peroxidation products, such as malonic dialdehyde, as well as diene and trienoic conjugates. Dynamics of the levels of lipid peroxidation products indicates that their blood serum concentration depends from glyphosate dose. The serum level of malonic dialdehyde after treatment with Gl at a dose of $50 \mathrm{mg} / \mathrm{kg}$ was found to increase 1.26 times compared to the untreated control whereas at the Gl dose of $100 \mathrm{mg} / \mathrm{kg}$ it increased 2.35 times, and 
at the Gl dose of $130 \mathrm{mg} / \mathrm{kg}$ a 2.65 -fold increase was seen. The levels of diene conjugates were $1.33,3.58$ and 5.91 times the untreated control levels $(\mathrm{p}<0.001)$ and triene conjugate levels were $2.54,3.81$ and 5.90 times the untreated control levels ( $\mathrm{p}<0.001$ ), at Gl doses of 50,100 and $130 \mathrm{mg} / \mathrm{kg}$, respectively. The amount of reduced glutathione after Gl poisoning at the dose of $50 \mathrm{mg} / \mathrm{kg}$ was reproducibly 1.40 times lower $(\mathrm{p}<0.001)$ compared to the untreated rats, whereas in Gl poisoning doses of 100 and $130 \mathrm{mg} / \mathrm{kg}$ the values were 1.70 and 2.64 times lower $(\mathrm{p}<0.001)$.

Acute poisoning with Gl led to a dose-dependent decrease in the activity of SOD and GTPR and an increase in $\mathrm{C}$ activity. In rats subjected to Gl poisoning at the doses of 50, 100 and $130 \mathrm{mg} / \mathrm{kg}$ the activity of SOD increased $1.40,1.70$ and 2.64 times, respectively, and the activity of GTPR increased 1.59, 2.21 and 4.77 times, respectively. Activity of $\mathrm{C}$ increased 1.31, 1.44 and 1.57 times, as the Gl dose increased.

The use of $\mathrm{S}$ led to a pronounced therapeutic effect in all tested doses of Gl. A significant decrease in the concentrations of all the studied lipid peroxidation markers was observed. The MDA content during the treatment of acute Gl poisoning at doses of 50,100 and $130 \mathrm{mg} / \mathrm{kg}$ decreased 1.40,1.50 and 1.49 times, the levels of DC decreased 1.75, 1.72 and 1.42 times, and TK levels demonstrated decreases of 1.55, 1.61 and 1.71 times, respectively.

The use of $\mathrm{S}$ had a pronounced normalizing effect on the activity of the studied enzymes. A significant increase in the activity of SOD was noted in the context of treatment of Gl poisoning with S. SOD levels were 1.21, 1.29 and 1.64 times increased, when the Gl doses were 50, 100 and $130 \mathrm{mg} / \mathrm{kg}$, respectively. Similarly, GLPR demonstrated increases of 1.38, 1.71 and 1.61 times, with increasing doses of Gl. The catalase activity decreased as the Gl dose increased with levels being 1.29, 1.33 and 1.40 times decreased, respectively (Table 1).

Table 1. Effect of experimental glyphosate poisoning on the lipid peroxidation activity and antioxidant protection system in albino rats

\begin{tabular}{|c|c|c|c|c|c|c|c|}
\hline Group & $\begin{array}{c}\text { Malonic } \\
\text { dialdehyde } \\
\text { mmol/L }\end{array}$ & $\begin{array}{c}\text { Diene } \\
\text { conjugates } \\
\text { mcmol/L }\end{array}$ & $\begin{array}{c}\text { Trienoic } \\
\text { conjugates } \\
\text { mcmol/L }\end{array}$ & $\begin{array}{c}\text { Reduced } \\
\text { glutathione } \\
\text { mmol/L }\end{array}$ & $\begin{array}{l}\text { Catalase } \\
\mathrm{mmol} / \mathrm{L}\end{array}$ & $\begin{array}{l}\text { Superoxide } \\
\text { dismutase } \\
\mathrm{mmol} / \mathrm{min}\end{array}$ & $\begin{array}{c}\text { Glutathi- } \\
\text { oneperoxi- } \\
\text { dase } \\
\mathrm{mmol} / \mathrm{min}\end{array}$ \\
\hline Healthy animals & $1.44 \pm 0.10$ & $0.12 \pm 0.01$ & $0.11 \pm 0.01$ & $4.52 \pm 0.50$ & $4.56 \pm 0.43$ & $1.36 \pm 0.11$ & $0.62 \pm 0.04$ \\
\hline $\begin{array}{c}\text { Glyphosate, } \\
50 \mathrm{mg} / \mathrm{kg}\end{array}$ & $2.55 \pm 0.09^{*}$ & $0.28 \pm 0.02 *$ & $0.28 \pm 0.06^{*}$ & $3.23 \pm 0.04^{*}$ & $5.96 \pm 0.03$ & $1.05 \pm 0.10^{*}$ & $0.39 \pm 0.03^{*}$ \\
\hline $\begin{array}{c}\text { Glyphosate, } \\
50 \mathrm{mg} / \mathrm{kg} \text {, sodium } \\
\text { selenite, } 2 \mu \mathrm{g} / \mathrm{kg}\end{array}$ & $1.82 \pm 0.01^{* *}$ & $0.16 \pm 0.01^{*, * *}$ & $0.18 \pm 0.01^{*, * *}$ & $4.15 \pm 0.01^{* *}$ & $4.63 \pm 0.20^{*}$ & $1.27 \pm 0.13$ & $0.54 \pm 0.03$ \\
\hline $\begin{array}{c}\text { Glyphosate, } \\
100 \mathrm{mg} / \mathrm{kg}\end{array}$ & $3.39 \pm 0.19 *$ & $0.43 \pm 0.03^{*}$ & $0.42 \pm 0.01^{*}$ & $2.74 \pm 0.21^{*}$ & $6.58 \pm 0.55^{*}$ & $0.86 \pm 0.02^{*}$ & $0.28 \pm 0.01 *$ \\
\hline $\begin{array}{c}\text { Glyphosate, } \\
100 \mathrm{mg} / \mathrm{kg}, \\
\text { sodium selenite, } \\
2 \mu \mathrm{g} / \mathrm{kg}\end{array}$ & $2.25 \pm 0.31^{*, * *}$ & $0.25 \pm 0.02^{*, * *}$ & $0.26 \pm 0.02 *, * *$ & $3.87 \pm 0.01^{* *}$ & $4.93 \pm 0.38^{* *}$ & $1.11 \pm 0.01$ & $0.48 \pm 0.01^{* *}$ \\
\hline $\begin{array}{l}\text { Glyphosate, } \\
130 \mathrm{mg} / \mathrm{kg}\end{array}$ & $3.82 \pm 0.04^{*}$ & $0.71 \pm 0.05^{*}$ & $0.65 \pm 0.15 *$ & $1.71 \pm 0.01^{*}$ & $7.14 \pm 0.59^{*}$ & $0.54 \pm 0.02^{*}$ & $0.13 \pm 0.04 *$ \\
\hline $\begin{array}{c}\text { Glyphosate, } \\
130 \mathrm{mg} / \mathrm{kg}, \\
\text { sodium selenite, } \\
2 \mu \mathrm{k} / \mathrm{kg}\end{array}$ & $2.56 \pm 0.21^{*, * *}$ & $0.50 \pm 0.08 *, * *$ & $0.38 \pm 0.04^{*, * *}$ & $3.33 \pm 0.01 *, * *$ & $5.10 \pm 0.36^{* *}$ & $0.89 \pm 0.01^{*, * *}$ & $0.21 \pm 0.01 *, * *$ \\
\hline
\end{tabular}

Note: * reliable difference $(\mathrm{p}<0.001)$ as to the corresponding index for the healthy animals;

** - reliable difference $(\mathrm{p}<0.001)$ in relation to the previous group

\section{Discussion}

In $1987 \mathrm{Gl}$ was in 17th place in the world in terms of frequency of use, and by 2001 it was the most frequently used herbicide [7]. The annual demand for Gl is about 500,000 tons, and sales in 2011 reached $\$ 5.6$ billion [1]. The main route of pesticide intake into the human system is alimentary $(95 \%$ of pesticides comes from food, $4.7 \%$ from water) [2]. Gl is associated with both the onset of infertility and impaired embryonic development in humans and animals [3]. In cattle that consumed feed grown in the presence of Gl a negative effect on the ability to reproduce was observed. In experiments on both cell cultures and animals (in vitro and in vivo), the ability of Gl to cause oxidative stress at low concentrations was established [8]. This is due to its ability to bind a number of ions (manganese, copper, cobalt, iron, zinc, calcium and magnesium), which leads to impaired mitochondrial 
function, impaired oxidative phosphorylation and the formation of large quantities of reactive oxygen species [9]. Kidney and liver damage are the most significant effects [9].

C, SOD, GLPR are enzymes that protect the cells from reactive forms of oxygen. Oxidases, the enzymes directly reducing oxygen, are involved in the neutralization of free radicals and are the most active in the liver, adrenals, and kidneys [10]. SOD is an oxidase that transforms super oxide anions into hydrogen peroxide. Superoxide dismutase is in the mitochondria and is the first line of protection against the toxic effects of lipid peroxidation. SOD is an induced enzyme, its synthesis being related to the lipid peroxidation processes in the cells. The oxidase system is not the only regulator of lipid peroxidation intensity, phospholipid detoxification also occurs via the enzymes of the glutathione system, in particular, GLPR, glutathione transferase and glutathione reductase [10].

GLPR inactivates active oxygen forms by destroying hydrogen peroxide and lipid hydroperoxides. In addition, GLPR catalyses reduction of peroxides with tripeptide glutathione ( $\gamma$-glutamyl-cysteinyl-glycine) [11]. The glutathione sulfhydryl group serves as an electron donor and, when oxidized, it forms the disulfide glutathione form. Oxidized glutathione is reduced by glutathione reductase. GLPR reduces lipid hydroperoxides in the membranes [11]. After the Gl poisoning, a gradual decrease in C, SOD, GLPR and glutathione reductase was seen in all studied Gl doses.

It should be noted that lipid peroxidation products are potential proinflammatory factors and play a crucial role in vascular endothelial lesions [12], are capable of inhibiting endothelium-dependent vascular relaxation and cause vasoconstrictory reactions. Clinical manifestations of increasing lipid peroxidation activity may include inflammation and functional impairment of various organs, especially the liver, kidneys and brain. Damage to the liver cells results in inhibition of the activity of the cytochrome oxidase enzymes CYP1A1/2 and CYP3A, which are involved in the metabolism of xenobiotics [11]. In our experiments, an increase in the activity of the hepatic intracellular enzymes like alanine aminotransferase and aspartate aminotransferase, which indicates damage of hepatocytes, was observed. Exposure to Gl is known to increase the levels of oxidized glutathione, free proline content, ion fluxes and the activity of catalase, peroxidase and glutathione-Stransferase [10]. Glutathione is one of the most widespread forms of organic sulfur and has various functions in animal organisms. First, it is a very important component of the protective and defence system. It acts as an antioxidant against active oxygen species. Glutathione takes part in glutathione-ascorbate shuttle (HalliwellAsada cycle) where it provides electrons for the reduction of ascorbate [13]. Reduction of glutathione is carried out by the enzyme glutathione reductase. In conjunction with the enzyme glutathione peroxidase, glutathione has a direct role as a scavenger of hydrogen peroxide. A well-known function of glutathione is detoxifying different xenobiotics, such as herbicides and heavy metals, by conjugation. This process can be accomplished with or without the participation of the enzyme glutathione-S-transferase [14]. This detoxifying process usually has two phases: conjugation and compartmentalization of the conjugates, which is usually in the vacuole or apoplast. The decrease in the activity of most enzymes of the antioxidant defence system can be explained by the depletion of these enzymes. The depletion is a result of overuse caused by a significant increase in the lipid peroxidation activity in response to the action of Gl.

The therapeutic effect of S was manifested not only in the normalization of the activity of lipid peroxidation processes, but also in the normalization of the functional state of the liver. S stimulates the synthesis of glutathione, which contributes to an increase in the antioxidant potential of the body and detoxification of lipoperoxides. In small and medium doses, the trace element provides effective antioxidant protection of mitochondria, stronger than even alpha tocopherol [15]. S protects proteins from attack of peroxynitrite and is a part of the glutathione peroxidase enzyme, which decomposes and detoxifies hydrogen peroxide [15]. The therapeutic effects of S are primarily associated with maintaining the function of selenium-containing enzymes, primarily glutathione peroxidase, and the enzymes involved in the deiodination of thyroid hormones. The antioxidant properties of $\mathrm{S}$ are enhanced by interaction with vitamin E [16]. A decrease of the level of selenium in the serum of blood has been seen in various pathologies. Selenium is involved in the processes of tissue respiration and oxidative phosphorylation. Its property is to stabilize sialic acid content, and neutralize free radicals. The results from this study provide justification for the possibility of using $\mathrm{S}$ as a therapeutic for acute Gl poisoning.

\section{Conclusions}

1. Experimental glyphosate poisoning is accompanied by an increase in the blood levels of the lipid peroxidation marker malonic dialdehyde (1.26, 2.36 and 2.65 fold increase at Gl doses of 50, 100 and 130 $\mathrm{mg} / \mathrm{kg}$, respectively).

2. Development of experimental glyphosate poisoning in doses 50,100 and $130 \mathrm{mg} / \mathrm{kg}$ is accompanied by decreased activity of the superoxide dismutase (1.40, 1.70 and 2.65 fold decrease, respectively), 
glutathione peroxidase (1.59, 2.21 and 4.77 fold decrease, respectively), and an increase in catalase activity (1.31, 1.44 and 1.57 fold increase, respectively).

3. Treatment of glyphosate poisoning with sodium selenite led to a reproducible normalization of the concentration of the lipid peroxidation markers and antioxidant system enzymes.

\section{References:}

1. Van Bruggen AHC, He MM, Shin K, Mai V, Jeong KC, Finckh MR, et al. Environmental and health effects of the herbicide glyphosate. Sci Total Environ. 2018; 616-617: 255-268. https://doi.org/10.1016/j.scitotenv.2017.10.309

2. Annett R, Habibi HR, Hontela A. Impact of glyphosate and glyphosate-based herbicides on the freshwater environment. J Appl Toxicol. 2014; 34(5): 458-79. https://doi.org/10.1002/jat.2997

3. Vandenberg LN, Blumberg B, Antoniou MN, Benbrook CM, Carroll L, Colborn T, et al. Is it time to reassess current safety standards for glyphosate-based herbicides?. J Epidemiol Community Health. 2017; 71(6): 613618. https://doi.org/10.1136/jech-2016-208463

4. Woods SL, Sobolewska S, Rose SP, Whiting IM, Blanchard A, Ionescu C, et al. Effect of feeding different sources of selenium on growth performance and antioxidant status of broilers. Br P Sci. 2020; 1-7. Epub 2020 Feb 7. https://doi.org/10.1080/00071668.2020.1716301

5. Council of Europe. European Convention for the Protection of Vertebrate Animals used for Experimental and Other Scientific Purposes, Strasbourg, $18^{\text {th }}$ March 1986. European Treaty Series No 123. Council of Europe: Strasbourg; 1986.

6. Vollhardt P, Neil E. Organic chemistry. $6^{\text {th }}$ edition. New York: WH Freeman \& Company; 2007.

7. Fahlgren N, Bart R, Herrera-Estrella L, Rellan-Alvarez R, Chitwood DH, Dinneny JR. Plant scientists: GM technology is safe. Science. 2016; 351(6275): 824-829. https://doi.org/10.1126/science.351.6275.824-a

8. Tang J, Hu P, Li Y, Win-Shwe T, Li C. Ion imbalance is involved in the mechanisms of liver oxidative damage in rats exposed to glyphosate. Front Physiol. 2017; 8: 1083. https://doi.org/10.3389/fphys.2017.01083

9. Turkmen R, Dogan I. Determination of acute oral toxicity of glyphosate isopropylamine salt in rats. Environ Sci Pollut Res Int. 2020; 20: 536-44. https://doi.org/10.1007/s11356-020-07643-5

10. Pala A. The effect of a glyphosate-based herbicide on acetylcholinesterase (AChE) activity, oxidative stress, and antioxidant status in freshwater amphipod: Gammarus pulex (Crustacean). Environ Sci Pollut Res Int. 2019; 26(36): 36869-36877. https://doi.org/10.1007/s11356-019-06804-5

11. Gronwald J, Plaisance K. Isolation and characterization of glutathione S-transferase isozymes from sorghum. Plant Physiol. 1998; 117(3): 877-892. https://doi.org/10.1104/pp.117.3.877

12. Cattani D, de Liz Oliveira Cavalli VL, Heinz Rieg CE, Tonietto Domingues J, Dal-Cim T, Tasca $\mathrm{CI}$, et al. Mechanisms underlying the neurotoxicity induced by glyphosate-based herbicide in immature rat hippocampus: involvement of glutamate excitotoxicity. Toxicology. 2014; 320: 34-45. https://doi.org/10.1016/j.tox.2014.03.001

13. Davis TZ, Tiwary AK, Stegelmeier BL, Pfister JA, Panter KP, Hall JO. Comparative oral dose toxicokinetics of sodium selenite and selenomethionine. J Appl Toxicol. 2017; 37(2): 231-238. https://doi.org/10.1002/jat.3350

14. Oestreicher J, Morgan B. Glutathione: subcellular distribution and membrane transport. Biochem Cell Biol. 2019; 97(3): 270-289. https://doi.org/10.1139/bcb-2018-0189

15. Turkyilmaz IB, Arda Pirincci P, Bolkent S, Yanardag R. The effects of vitamins and selenium mixture or ranitidine against small intestinal injury induced by indomethacin in adult rats. J Food Biochem. 2019; 43(4): e12808-16. https://doi.org/10.1111/jfbc.12808

16. Doan N, Liu Y, Xiong X, Kim K, Wu Z, Bravo DM, et al. Organic selenium supplement partially alleviated diquat-induced oxidative insults and hepatic metabolic stress in nursery pigs. Br J Nutr. 2020; 2: 1-31. https://doi.org/10.1017/S0007114520000689 